\title{
Penyisihan Nutrien Nitrogen pada Limbah Cair Artifisial NPK Menggunakan Sistem Floating Treatment Wetlands (FTWs)
}

\author{
Sugiarti ${ }^{1}$, Nurul Setiadewi ${ }^{1}$, Dian Oktaviyani ${ }^{1}$ dan Denalis Rohaningsih ${ }^{1}$
}

${ }^{1}$ Pusat Penelitian Limnologi - Lembaga Ilmu Pengetahuan Indonesia. Kabupaten Bogor; e-mail: ade@limnologi.lipi.go.id

\begin{abstract}
ABSTRAK
Lahan Basah Terapung atau Floating Treatment Wetlands (FTWs) merupakan salah satu alternatif pengolahan limbah secara alamiah untuk mengurangi kadar polutan pada suatu badan air dengan memanfaatkan akar tanaman sebagai penyerap polutan tersebut. Penelitian ini merupakan kajian awal pengolahan limbah pupuk NPK (dengan dasar senyawa N pada konsentrasi tertentu, menggunakan sistem FTW. Penelitian ini bertujuan untuk mengetahui efisiensi penyisihan konsentrasi nutrien nitrogen, antara lain ammonia, nitrat, dan total nitrogen (TN), di dalam limbah cair artifisial NPK menggunakan sistem FTWs dengan pemanfaatan tanaman melati air (Echinodorus berteroi (Spreng.) Fassett) dan pisang-pisangan (Helliconia psittaforum) sebagai penyerap nutrien tersebut. Hasil penelitian ini diharapkan dapat menjadi bahan untuk rekomendasi alternatif teknologi pengolahan dalam mengatasi masalah pencemaran di perairan. Kolam percobaan sejumlah 4 (empat) diisi pupuk NPK sebagai limbah artifisial dengan konsentrasi N sebesar $2 \mathrm{mg} /$ L. Kolam 1 merupakan kolam kontrol, kolam 2 berisi FTWs tanpa tanaman, kolam 3 berisi FTWs dengan tanaman melati air, dan kolam 4 berisi FTWs dengan tanaman pisangpisangan. Sampling air dilakukan pada hari ke 3, 10, 24, 35, dan 112. Parameter yang diukur adalah pH, suhu air, kekeruhan, konduktivitas, oksigen terlarut, ammonia, nitrat, dan TN. Tanaman melati air dapat menyisihkan ammonia sebesar 91,19\%, nitrat sebesar $100 \%$ dan TN sebesar 77,04\%. Sedangkan, tanaman pisang-pisangan dapat menyisihkan ammonia sebesar $90,30 \%$, nitrat sebesar $100 \%$ dan TN sebesar $67,12 \%$. Kedua jenis tanaman menunjukkan pertumbuhan yang baik, yang ditandai dengan tumbuhnya daun, batang, bunga, dan akar tanaman. Hal ini menunjukkan bahwa kedua jenis tanaman tersebut memiliki kemampuan menyerap nutrien nitrogen secara efektif melalui sistem pengolahan FTWs.
\end{abstract}

Kata kunci: Nutrien N, Limbah cair artifisial NPK, Penyisihan konsentrasi, Tanaman air, Floating Treatment Wetlands

\begin{abstract}
Floating Treatment Wetlands (FTWs) is an alternative natural waste treatment which is able to reduce contaminants contained in a water body by utilizing plant roots as an absorber of any pollutants. This research is a preliminary study of NPK fertilizer waste processing (based on $\mathrm{N}$ compounds at certain concentrations, using the FTW system).This study aims to determine the efficiency of removal of nitrogen nutrients, including ammonia, nitrate, and total nitrogen (TN), in NPK artificial wastewater using the FTW system. This FTW system utilized Echinodorus teroi (Spreng.) Fassett and Helliconia psittaforum as absorbers of nitrogen nutrient. The results of this study are expected to be the material for recommendations for alternative processing technologies in overcoming the problem of pollution in waters. Four experimental ponds were filled with NPK fertilizer as an artificial waste with nitrogen concentration of $2 \mathrm{mg} / \mathrm{L}$. Pool 1 was a control pool, pool 2 contained FTW without plants, pool 3 contained FTW with Echinodorus teroi (Spreng.) Fassett, and pool 4 contains FTW with Helliconia psittaforum. Water sampling was carried out on days $3,10,24,35$, and 112 . The parameters measured were $\mathrm{pH}$, air temperature, turbidity, conductivity, dissolved oxygen, ammonia, nitrate, and TN. Echinodorus teroi (Spreng.) Fassett can remove ammonia by 91,19\%, nitrate by $100 \%$ and TN by $77,04 \%$. Meanwhile, Helliconia psittaforum can remove ammonia by $90,30 \%$, nitrate by $100 \%$ and TN by $67,12 \%$. Both types of plants showed good growth, which was indicated by the leaves growth, as well as the stems, flowers and roots. This showed that both types of plants have the ability to absorb nutrients effectively through the FTWs processing system.
\end{abstract}

Keywords: Nutrient N, Artificial NPK wastewater, Reduction in concentration, Water plants, Floating Treatment Wetlands

Citation: Sugiarti, Setiadewi, N., Oktaviyani, D., dan Rohaningsih, D. (2020). Penyisihan Nutrien Nitrogen pada Limbah Cair Artifisial NPK Menggunakan Sistem Floating Treatment Wetlands (FTWs). Jurnal Ilmu Lingkungan, 18(3), 595-601, doi:10.14710/jil.18.3.595-601

\section{Latar Belakang}

Lahan Basah Terapung atau Floating Treatment Wetlands (FTWs) merupakan salah satu alternatif pengolahan limbah secara alamiah untuk mengurangi cemaran pada suatu badan air dengan memanfaatkan akar tanaman sebagai penyerap polutan. Sistem FTWs tersusun dari tanaman-tanaman emergent (mencuat dengan akar menempel pada substrat) yang ditempatkan pada bak-bak yang mengapung di badan air yang berfungsi untuk pengolahan air dan estetika. 
Selain itu, perakaran tanaman yang menggantung di dalam kolom air akan mengambil nutrisi langsung dari perairan (Keizer-vlek et al.,2014). FTWs dibentuk menggunakan media apung yang mendukung pertumbuhan tanaman secara hidrofonik (Sample \& Fox, 2013). Secara umum FTWs terdiri atas tanaman air, media tanam dan media apung (bouyant material dan bouyant mat) serta sistem tambatan (anchoring) (Pusparinda dan Santoso, 2016).

FTWs juga memberikan banyak keuntungan bagi ekosistem perairan antara lain menjadi tempat feeding ground (tempat mencari makan), nursery ground (tempat pengasuhan) dan refuge ground (tempat perlindungan) bagi ikan-ikan yang ada di perairan tersebut. Hal ini dikarenakan tanaman yang tumbuh pada FTWs memiliki perakaran yang rimbun dan menjadi tempat berkumpulnya banyak organisme akuatik. Sistem ini juga dapat menjadi salah satu alternatif untuk memecahkan masalah eutrofikasi yang terjadi pada perairan terutama di wilayah perkotaan karena tidak memerlukan lahan yang besar danluas. FTW juga memiliki kelebihan dibandingkan constructed wetland karena dapat mengikuti fluktuasi tinggi muka air dan dapat diaplikasikan pada lokasilokasi yang memiliki keterbatasan lahan, khususnya di kota-kota besar (Keizer-vlek et al.,2014). Winston et al.(2013) juga menyatakan sistem FTW berfungsi sebagai sistem hidroponik, dimana tanaman dan mikroba tumbuh pada media terapung dan menyerap nutrien untuk tumbuh bersama-sama.Tanaman air dapat menurunkan kadar pencemar secara langsung yaitu dengan menyerap unsur-unsur pencemar sebagai sumber nutrien atau secara tidak langsung dengan menjadi media tumbuh bagi mikroorganisme yang akan mengurai bahan pencemar serta memasok oksigen untuk proses-proses penguraian yang bersifat anaerobik (Sunanisari dkk, 2008).

Penelitian ini merupakan kajian awal pengolahan limbah pupuk NPK (dengan dasar senyawa N pada konsentrasi tertentu), menggunakan sistem FTW. Media tanam yang digunakan yaitu tanah, media apungnya berupa pipa paralon dan bouyant mat yang terdiri atas tali, lapisan karet, dan sekam.Tanaman air yang digunakan adalah melati air dan pisang-pisangan merupakan jenis tumbuhan air yang termasuk ke dalam tipe emergent. Secara morfologi tipe emergent lebih mudah bertahan hidup pada air yang berarus dibandingkan tipe lainnya, karena akarnya yang menempel pada substrat akan menahannya untuk tetap berada di posisi semula sedangkan batang dan daunnya mencuat di atas permukaan airtidak akan terlalu dipengaruhi oleh arus. Perakaran tanaman air tanaman melati air (Echinodorus berteroi (Spreng.) Fassett) dan pisang-pisangan (Helliconia psittaforum) yang rimbun dapat mengurangi kecepatan aliran air sehingga padatan yang tersuspensi mempunyai kesempatan untuk mengendap.

Penelitian sebelumnya oleh Handajani dkk (2018), bahwa sistem FTW dengan menggunakan tanaman melati air atau water jasmine (Echninodorus palaefolius) mampu menyisihkan nutrient dari limbah 596 yang dihasilkan dari aktivitas perikanan. Penyisihan total nitrogen, nitrit, dan nitrat yang dihasilkan berturut-turut sebesar 27\%, 45\%, dan 21\%, dalam periode pengamatan 60 hari. Pada penelitian tersebut juga disebutkan bahwa kemampuan tanaman melati air dalam menyerap polutan, lebih besar bila dibandingkan dengan tanaman lain (dalam penelitian digunakan Echinodorus amazonicus). Hal ini juga ditandai dengan pertumbuhan tanaman tersebut sebagai salah satu indikator keberhasilan sistem FTW.

Sementara itu, penelitian lain oleh Konnerupet al. (2009), dijelaskan bahwa penggunaan tanaman air jenis Heliconia juga mampu menyisihkan kandungan nutrient pada air limbah melalui sistem pengolahan lahan basah. Laju penyisihan nutrient TN menggunakan Heliconia diperoleh sebesar 0.0093 $\mathrm{m} /$ hari. Berdasarkan hasil penelitian tersebut, tanaman air Heliconia mampu tumbuh dengan baik dengan juga adanya produksi biomassa selama proses penyisihan berlangsung.

Sebagai kajian awal, penelitian ini bertujuan untuk mengetahui efisiensi penyisihan kadar nitrogenyang terdapat pada limbah pupuk NPK.Hasil penelitian ini diharapkan dapat menjadi bahan untuk rekomendasi alternatif teknologi pengolahan dalam mengatasi masalah pencemaran di perairan.

\section{Bahan dan Metode}

Sistem FTW dilakukan pada skala laboratorium di Pusat Penelitian Limnologi - LIPI, Cibinong. Waktu percobaan dari bulan Juli hingga pertengahan Oktober tahun 2019. Penelitian ini menggunakan kolam beton sebanyak 4 (empat) buah, dengan dimensi panjang $\mathrm{x}$ lebar x kedalaman sebesar 1,8 x 1,2 x 1,0 meter. Berdasarkan studi literatur oleh Pusparinda dan Santoso (2016), bahwa kedalaman air menurut kriteria desain perencanaan FTW adalah $>0.8$ meter.

Masing-masing kolam dimasukkan limbah buatan berupa pupuk NPK dengan konsentrasi N sebesar 2 mg/L sebanyak 2000 Liter. Tanaman yang digunakan pada penelitian ini adalah tanaman melati air (Echinodorus berteroi (Spreng.) Fassett) dan pisangpisangan (Helliconia psittaforum). Kolam 1 merupakan kolam kontrol, kolom 2 berisi FTWs tanpa tanaman air, kolam 3 berisi FTWs dengan tanaman melati air dan kolam 4 berisi FTWs dengan tanaman pisang-pisangan. Jumlah tanaman air yang ditanam pada media FTW sebanyak 15 lubang. Pada tahap awal penelitian, panjang batang diseragamkan menjadi sepanjang $20 \mathrm{~cm}$ dan telah tumbuh akar pada kedua jenis tanaman tersebut (Gambar 1).

Sampling air dilakukan pada hari ke 3, 10, 24, 35 dan 112 dengan pertimbangan pada hari - hari tersebut telah terjadi reaksi penyisihan nutrient $\mathrm{N}$ pada kolam pemantauan. Pengukuran parameter kualitas air, antara lain $\mathrm{pH}$, suhu air, kekeruhan, konduktivitas dan DO, dilakukan secara in situ menggunakan instrumen WQC (Water Quality Checker) merk YSI Pro. Analisis nutrien N dilakukan di laboratorium dengan alat utama yaitu Spektrofotometer UV-VIS. Parameter ammonia 
dianalisis dengan metode phenat, nutrien nitrat dianalisis dengan metode brucine yang dimodifikasi, dan TN dianalisis dengan metode destruksi yang dilanjutkan dengan metode brucine yang dimodifikasi (APHA, 2017).
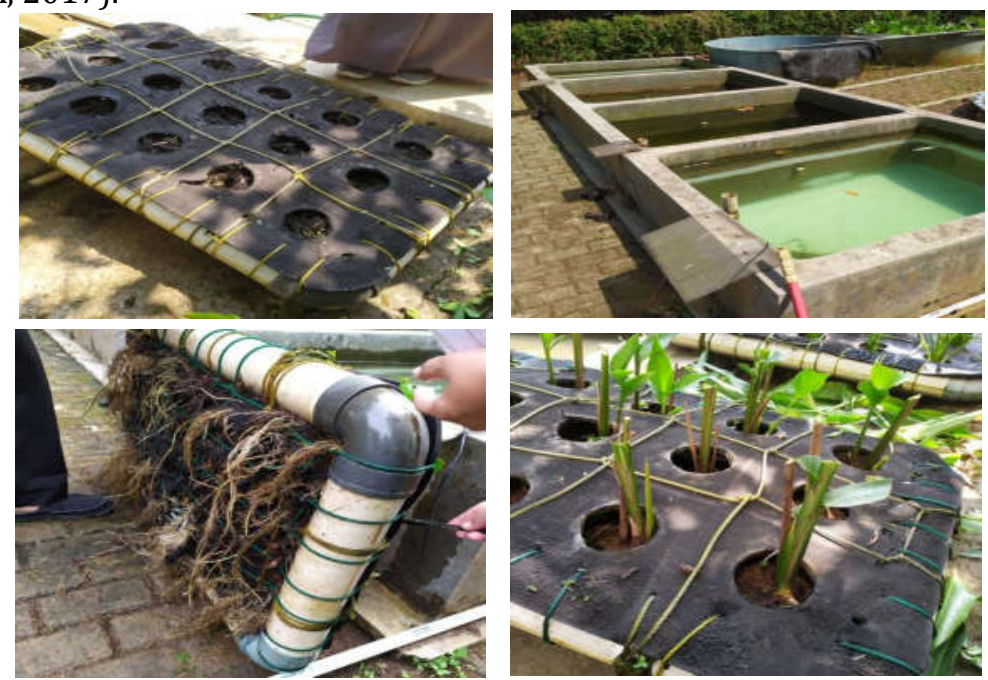

Gambar 1. Sistem Floating Treatment Wetlands(FTWs) Skala Laboratorium

$$
\% E R=\frac{C_{\text {in }}-C_{\text {out }}}{C_{\text {in }}}
$$

Dimana, Cin adalah konsentrasi nutrient awal dan Cout adalah konsentrasi nutrient akhir, dalam satuan $\mathrm{mg} / \mathrm{L}$.

\section{Hasil dan Pembahasan}

\subsection{Pengukuran Kualitas Air Pada Sistem FTWs}

Pengukuran kualitas air dilakukan untuk melihat pengaruh sistem FTWs terhadap kualitas air. Hasil pengukuran suhu, pH, ORP, Total Dissolved Solid (TDS), kekeruhan, dan konduktivitas dapat dilihat pada Gambar 2-3.

Hasil pengukuran suhu pada eksperimen FTW menunjukkan tren fluktuatif yang cenderung
Efisiensi penyisihan (Efficiency Removal atau ER) nutrien ammonia, nitrat dan TN dalam \% dihitung dengan rumus berikut ini:

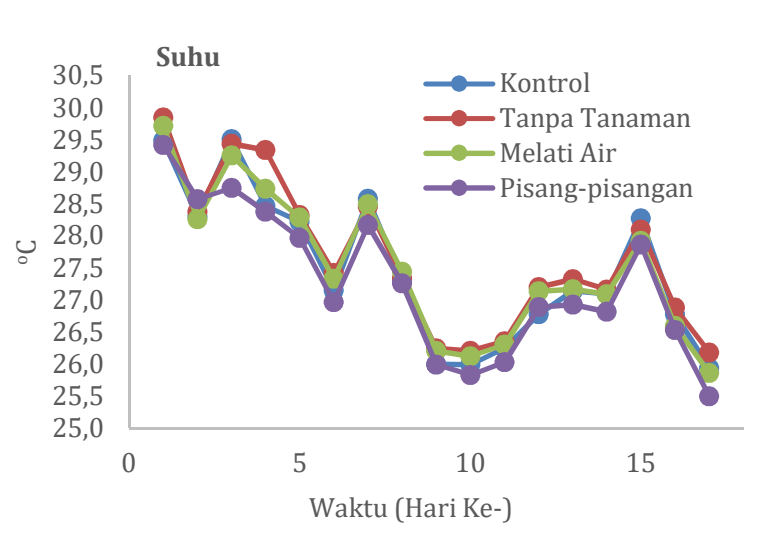

menurun (Gambar 2). Namun, rentang suhu selama proses pengolahan masih pada kisaran suhu normal yakni sebesar $25,50-29,85^{\circ} \mathrm{C}$. Suhu sangat berperan mengendalikan kondisi ekosistem perairan yang berpengaruh bagi pertumbuhan organisme akuatik (Effendi, 2002). Parameter suhu berpengaruh terhadap aktivitas baik mikroorganisme maupun tanaman. Hal ini akan berdampak bagi performa suatu sistem pengolahan air limbah (Astuti et al., 2017). Penelitian oleh Setiyanto (2016), disebutkan bahwa suhu optimum untuk pertumbuhan tanaman melati air berada pada kisaran $25-35^{\circ} \mathrm{C}$. Dengan demikian, berdasarkan hasil pengamatan pada penelitian ini, menandakan bahwa kondisi lingkungan dalam sistem FTW berlangsung dengan baik dan optimal.

Gambar 2.Distribusi Nilai Suhu dan pH pada Eksperimen FTWs

Nilai pH rata-rata yang dihasilkan pada penelitian ini berada pada nilai yang stabildan tidak ada perubahan yang dratis. Besaran $\mathrm{pH}$ pada perairan merupakan indikator penting dalam penentuan kualitas air dan pencemaran badan air (Fisesa et al., 2014). Pada sistem pengolahan menggunakan lahan basah, nilai pH diharapkan berada pada kondisi atau mendekati netral, karena hal ini akan berpengaruh terhadap proses fotosintesis tanaman dan aktivitas mikroorganisme dalam sistem pengolahan (Sari dkk, 2015). Kaswinarni (2007) menjelaskan bahwa pada pH yang berada diluar batas normal, seperti dibawah 
4.0 atau diatas 9.5, dapat mengganggu kestabilan pertumbuhan mikroorganisme. Nilai $\mathrm{pH}$ pada penelitian cenderung netral pada kisaran 7-8.5. Dengan demikian, berdasarkan hasil pengamatan

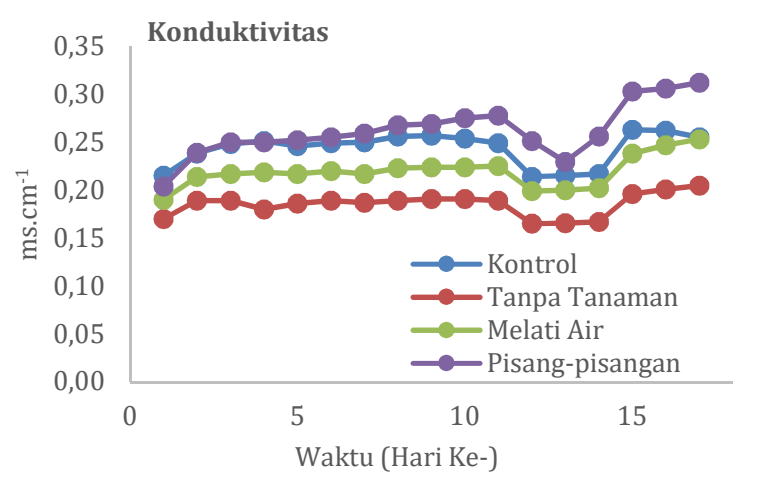

pada penelitian ini, menandakan bahwa kondisi lingkungan dalam sistem FTW berlangsung dengan baik.

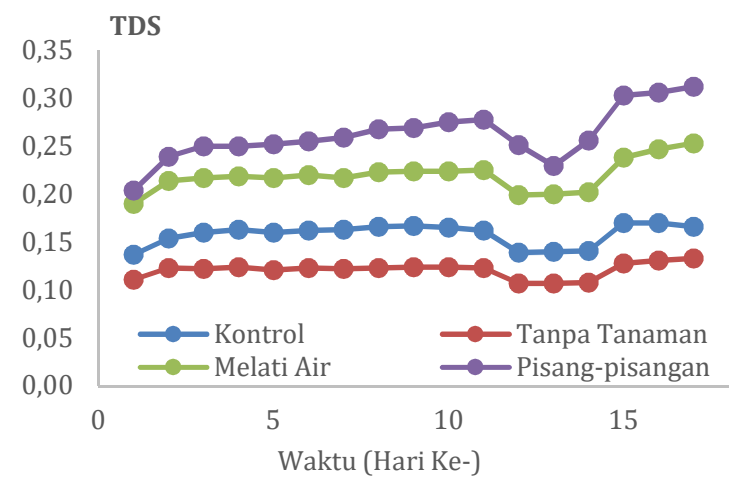

Gambar 3. Distribusi Nilai TDS dan Konduktivitas pada Eksperimen FTWs

Nilai konduktivitas menunjukkan pola yang cukup stabil yakni pada rentang $0,143-0,132 \mathrm{mS} / \mathrm{cm}$, dapat dilihat pada Gambar 3. Pola yang stabil juga terjadi pada hasil pengukuran parameter TDS yakni pada kisaran 0,106 - 0,203 g/L. Nilai konduktivitas memiliki hubungan linier dengan TDS (Irwan, 2016). Konduktivitas dipengaruhi oleh konsentrasi ion yang terkandung di dalam larutan. Dalam hal ini, limbah NPK pada air sistem FTWs akan terionisasi dan mempengaruhi konduktivitasnya. Semakin tinggi nilai TDS, maka semakin besar pula konduktivitas perairan tersebut (Nicola et al., 2015).

Nilai ORP erat kaitannya dengan substansi pengoksidasi, yaitu oksigen. Nilai ORP sedikit dipengaruhi oleh suhu, namun sangat dipengaruhi oleh kadar oksigen (Effendi, 2002). Pada pengamatan hari ke 19 s/d 22, nilai ORP cenderung menurun (Gambar 4). Sedangkan, nilai turbiditas pada hari

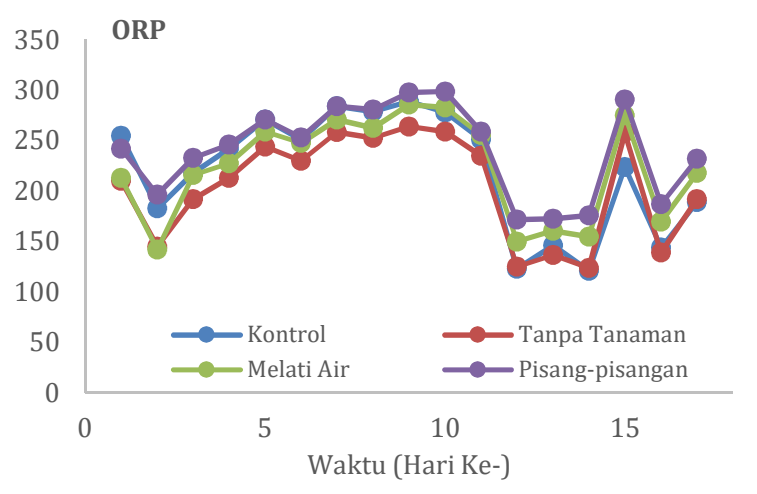

yang sama cenderung meningkat. Kondisi air kemungkinan menjadi anaerob dengan banyaknya material tersuspensi yang menyebabkan naiknya nilai turbiditas. Berdasarkan Gambar 2, 3 dan 4, bahwa tren nilai $\mathrm{pH}$, konduktivitas, ORP dan turbiditas serta konsentrasi kurang lebih sama. Nilai $p H$, konduktivitas dan ORP serta konsentrasi TDS cenderung stabil dari hari ke-1 sampai ke-15 untuk setiap kolam. Pada hari ke-19 sampai hari ke-22, dengan naiknya nilai turbiditas yang ditandai dengan perubahan warna air dari keempat kolam, maka nilai pH, konduktivitas dan ORP serta konsentrasi TDS cenderung menurun. Warna air pada keempat kolam mulai hijau yang kemungkinan disebabkan material tersuspensi di kolom air. Pada hari ke-23 dan seterusnya nilai $\mathrm{pH}$, konduktivitas dan ORP serta konsentrasi TDS cenderung stabil kembali.

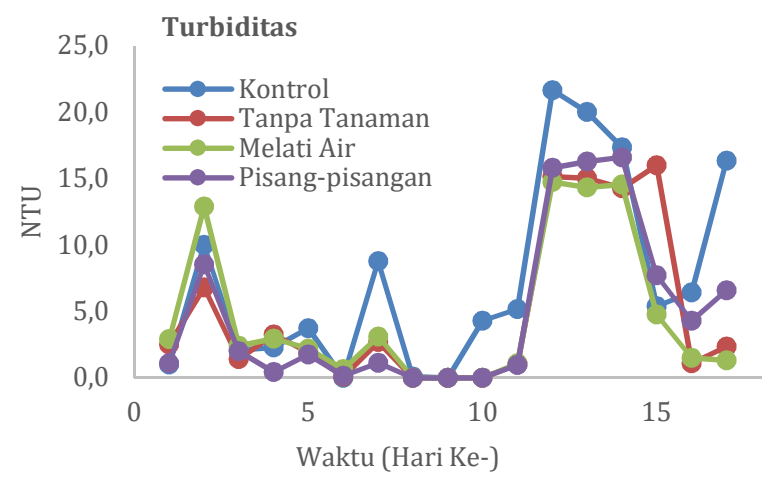

Gambar 4.Distribusi Nilai ORP dan Turbiditas pada Sistem FTWs

\subsection{Pengukuran Penyisihan Nutrien N Pada FTWs}

Hasil penyisihan nutrien $\mathrm{N}$ pada FTWs dapat dlihat pada Gambar 5, 6 dan 7. Nitrat penyisihannya $100 \%$ di semua kolam pada hari ke 112.Tanaman melati air dapat menyisihkan konsentrasi ammonia sebesar 91,19\%, konsentrasi nitrat sebesar 100\% dan konsentrasi TN sebesar 77,04\%, sedangkan tanaman pisang-pisangan dapat menyisihkan konsentrasi ammonia sebesar 90,30\%, konsentrasi nitrat sebesar $100 \%$ dan konsentrasi TN sebesar 67,12\%.

Nilai penyisihan konsentrasi ammonia dan nitrat di kolam FTW oleh tanaman pisang - pisangan lebih kecil dibandingkan tanaman melati air karena tanaman pisang - pisangan lebih sedikit menyerap nutrient $\mathrm{N}$ dibandingkan tanaman melati air. Luas permukaan tanaman pisang - pisangan lebih sedikit 
dibandingkan tanaman melati air. Struktur tanaman melati air dengan daun, bunga, batang dan akar cenderung menyerap nutrient $\mathrm{N}$ lebih banyak dibandingkan tanaman pisang - pisangan.

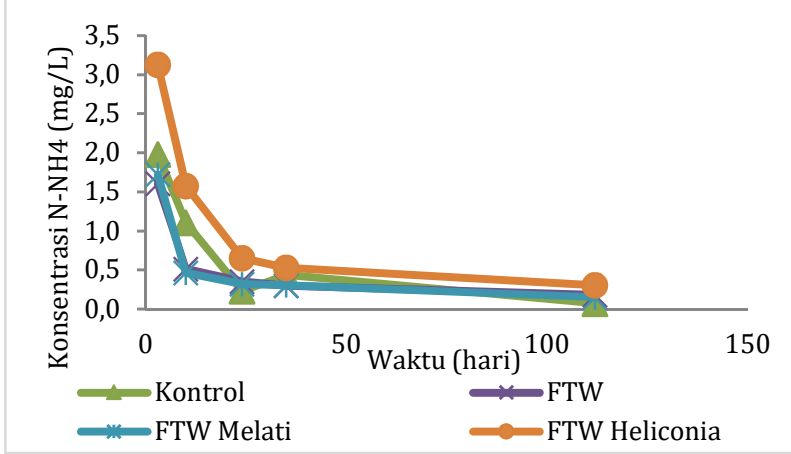

Gambar 5. Tren Efisiensi Konsentrasi Ammonia pada Sistem FTWs untuk Pengolahan Limbah Artifsial NPK

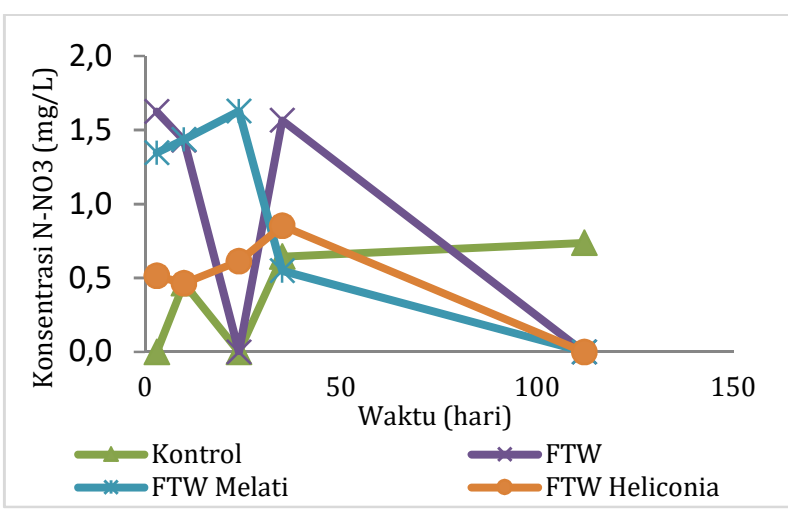

Gambar 6. Tren Efisiensi Konsentrasi Nitrat pada Sistem FTWs untuk Pengolahan Limbah Artifsial NPK

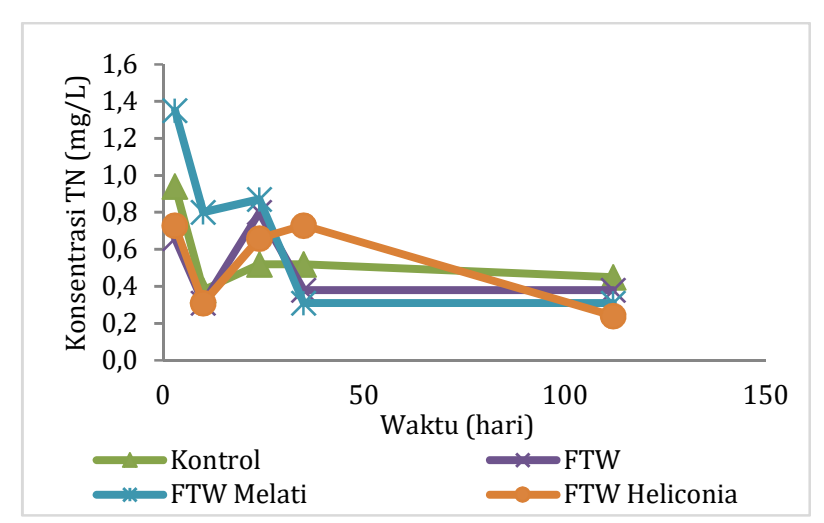

Gambar 7. Tren Efisiensi Konsentrasi TN pada Sistem FTWs untuk Pengolahan Limbah Artifsial NPK

Konsentrasi awal N-NH${ }_{4}$ di kolam heliconia lebih besar dari kolam melati air karena terjadi reaksi amonifikasi di kolam heliconia sedangkan di kolam melati air terjadi reaksi nitrifikasi. Nilai ORP di hari hari awal di kolam heliconia lebih rendah daripada nilai ORP di melati air (Gambar 4.) Penurunan konsentrasi ammonia sangat besar terjadi pada 10 hari pertama. Kemungkinan besar terjadi reaksi nitrifikasi. Nitrat adalah hasil akhir dari oksida $\mathrm{N}$ di perairan. Konsentrasi nitrat yang tinggi menunjukkan adanya reaksi oksidasi(Sunjono dan Moersidik,
2015).Kadar oksigen cukup menunjang reaksi pembentukan nitrat sebelum hari ke 112 dimana konsentrasi oksigen terlarut berkisar antara 5 - 10 mg/L. Nilai ORP juga menunjukkan kondisi oksidasi dengan nilai yang cenderung naik di semua kolam (Gambar 4).

Pada hari ke-10 sampai hari ke-24, konsentrasi nitrat terutama di kolam FTW cenderung menurun. Nilai ORP yang cenderung menurun menandakan terjadinya reduksi dan pembentukan ammonia di kolom air.Pada hari ke 112, konsentrasi nitrat di semua kolam mendekati nol. Pada nilai pH yang cenderung asam di semua kolam (Gambar 2.), kesetimbangan ammonia dan amoniak cenderung mengarah ke pembentukan ammonia (Mayunar, 1990).

Reaksi $\mathrm{NH}_{4}{ }^{+} \leftrightarrow \mathrm{NH}_{3}+\mathrm{H}^{+}$dipengaruhi oleh $\mathrm{pH}$, suhu dan salinitas. Kesetimbangan bergeser ke arah pembentukan ammonia pada saat $\mathrm{pH}$ turun, suhu naik dan salinitas turun.Pada saat oksigen rendah keseimbangan akan menuju ammonia dan sebaliknya (Mayunar, 1990).

Tanaman air yang digunakan pada FTWs dapat menurunkan konsentrasi nutrient $\mathrm{N}$ dalam pada air, terlihat dari pertumbuhan yang baik dari kedua tanaman pada FTWs, yang ditandai tumbuhnya daun, batang dan bunga tanaman (Gambar 8). Tanaman melati air tumbuh baik dengan munculnya bunga dan pertumbuhan batang dan daun yang baik. Tanaman pisang - pisangan tumbuh tinggi dengan pertumbuhan kelopak daun yang baik.Perakaran tanaman yang menggantung di dalam kolom air akan mengambil nutrisi langsung dari perairan (Keizervlek et al.,2014). Nutrien $\mathrm{N}$ dipakai tanaman untuk menunjang pertumbuhannya. Winston et al.(2013) juga menyatakan tanaman dan mikroba tumbuh pada media terapung dan menyerap nutrien untuk tumbuh bersama-sama. Tanaman air dapat menurunkan kadar pencemar secara langsung yaitu dengan menyerap unsur-unsur pencemar sebagai sumber nutrien atau secara tidak langsung dengan menjadi media tumbuh bagi mikroorganisme yang akan mengurai bahan pencemar serta memasok oksigen untuk proses-proses penguraian yang bersifat anaerobic (Sunanisari dkk, 2008).

Dari penelitian ini terlihat bahwa tanaman pisang - pisangan dan melati air dapat dipakai untuk menurunkan konsentrasi cemaran nitrogen pada perairan. Walaupun demikian, tetap diperlukan penelitian lanjutan pada konsentrasi nutrient $\mathrm{N}$ yang berbeda-beda. Penelitian lain dengan FTW menggunakan tanaman melati air seperti dilaporkan oleh Handajani dkk (2018), bahwa sistem FTW dengan menggunakan tanaman melati air atau water jasmine (Echninodorus palaefolius) mampu menyisihkan nutrient dari limbah yang dihasilkan dari aktivitas perikanan. Penyisihan total nitrogen, nitrit, dan nitrat yang dihasilkan berturut-turut sebesar 27\%, 45\%, dan 21\%, dalam periode pengamatan 60 hari. Pada penelitian tersebut juga 
disebutkan bahwa kemampuan tanaman melati air dalam menyerap polutan, lebih besar bila dibandingkan dengan tanaman lain (dalam penelitian digunakan Echinodorus amazonicus). Hal ini juga ditandai dengan pertumbuhan tanaman tersebut sebagai salah satu indikator keberhasilan sistem FTW. Sementara itu, penelitian lain oleh Konnerup et al. (2009), dijelaskan bahwa penggunaan tanaman air jenis Heliconia juga mampu menyisihkan kandungan nutrient pada air limbah melalui sistem pengolahan lahan basah. Laju penyisihan nutrient TN menggunakan Heliconia diperoleh sebesar 0,0093 $\mathrm{m} /$ hari. Berdasarkan hasil penelitian tersebut, tanaman air Heliconia mampu tumbuh dengan baik dengan juga adanya produksi biomassa selama proses penyisihan berlangsung.
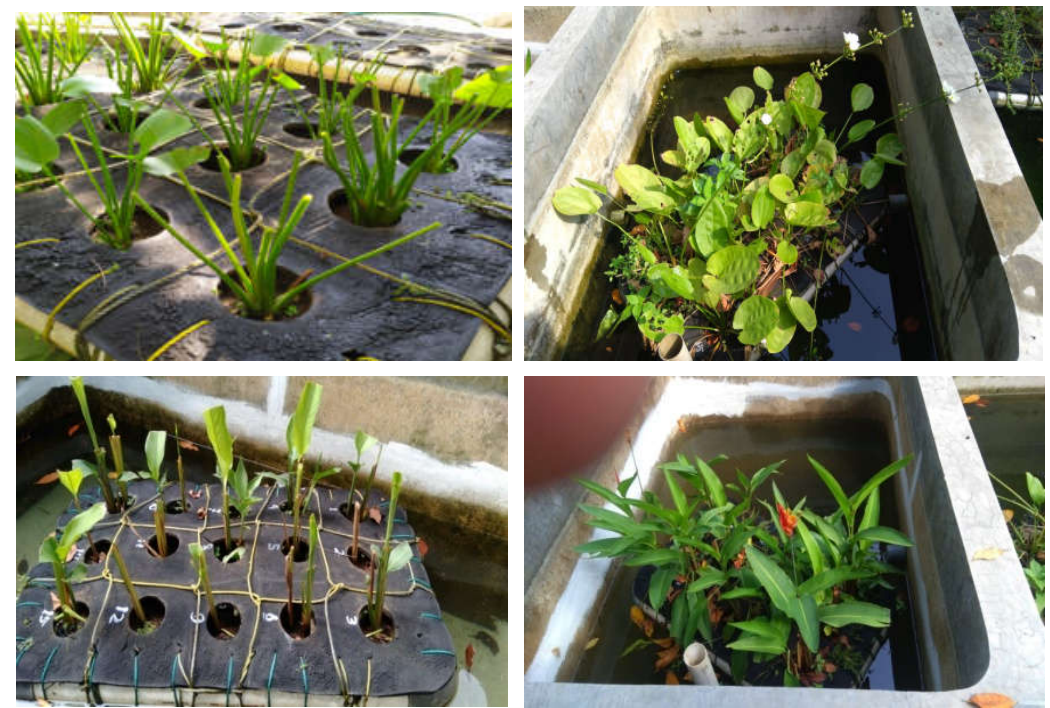

Gambar 8. Pertumbuhan Tanaman Melati Air (Kiri dan Kanan Atas) dan Pisang - Pisangan (Kiri dan Kanan Bawah) dalam Sistem FTWs

\section{Kesimpulan}

Floating Treatment Wetlands menggunakan tanaman melati air (Echinodorus berteroi (Spreng.) Fassett) dan pisang-pisangan (Strelitzia reginae Banks) mampu menurunkan konsentrasi nutrien $\mathrm{N}$. Tanaman melati air dapat menyisihkan konsentrasi ammonia sebesar 91,19\%, konsentrasi nitrat sebesar $100 \%$ dan konsentrasi TN sebesar 77,04\%, sedangkan tanaman pisang-pisangan dapat menyisihkan konsentrasi ammonia sebesar 90,30\%, konsentrasi nitrat sebesar $100 \%$ dan konsentrasi TN sebesar $67,12 \%$. Kedua jenis tanaman menunjukkan pertumbuhan yang baik, dengan ditandai tumbuhnya daun, batang, bunga, dan akar tanaman. Hal ini menunjukkan bahwa kedua jenis tanaman tersebut mampu menyerap fosfat secara efektif melalui sistem FTWs.

\section{DAFTAR PUSTAKA}

APHA (American Public Health Association). 2017. Standard Methods for The Examination of Water and Wastewater. American Public Health Association (APHA), 23th ed. American Water Works Association (AWWA) and Water Pollution Control Federation (WPCF). 1546 pp.

Astuti, A. D., Lindu, M., Yanidar, R., Kleden, M. 2017. Kinerja Subsurface Constructed Wetland Multylayer Filtration Tipe Aliran Vertikal Dengan Menggunakan Tanaman Akar Wangi (Vetivera Zozanoides) dalam Penyisihan BOD dan COD Air Limbah Kantin. Penelitian dan Karya Ilmiah. Vol. 1 No. 2. Pages 91-108.
Konnerup, D., Koottatep, T., Brix, H. 2009. Treatment of domestic wastewater in tropical, subsurface flow constructed wetlands planted with Canna and Heliconia. Ecological Engineering. Vol. 35. Pages 248257.

Effendi, Hefni. 2002. Telaah Kualitas Air Bagi Pengelolaan Sumber Daya dan Lingkungan Perairan. Penerbit Kanisius. 257 hal.

Fisesa, E. D., Setyobudiandi, Isdradjad., Krisanti, Majariana. 2014. Water Quality Condition and Community Structure of Macrozoobenthos in Belumai River, Deli Serdang District, North Sumatra Province. Depik. Vol. 3. Pages 1-9.

Handajani, H., Widanarni., Budiardi, T., Setiawati, M., Sujono. 2018. Phytoremediation of Eel (Anguila bicolor bicolor) Rearing Wastewater Using Amazon Sword (Echinodorus amazonicus) and Water Jasmine (Echinodorus palaefolius). Omni-Akuatika. Vol. 14 No. 2. Pages 43-51.

Irwan, F., Afdal. 2016. Analisis Hubungan Konduktivitas Listrik dengan Total Dissolved Solid (TDS) dan Temperatur pada Beberapa Jenis Air. Jurnal Fisika Unand. Vol. 5 No. 1. Pages 85-93.

Kaswinarni, F. 2007. Kajian Teknis Pengolahan Limbah Padat Dan Cair Industri Tahu (Studi Kasus Industri Tahu Tandang Semarang, Sederhana Kendal, dan Gagak Sipat Boyolali). In Universitas Diponegoro.

Keizer-Vlek, H. E., Piet F.M. Verdonschot, Ralf C.M. Verdonschot, Dorine Dekkers. 2014. The Contribution of Plant Uptake to Nutrient Removal by Floating Treatment Wetlands. Ecological Engineering. Vol. 73. Pages 684-690.

Mayunar. 1990. Pengendalian Senyawa Nitrogen pada Budidaya Ikan dengan Sistem Resirkulasi. Oseana. Vol. XV No. 1. Hal 43-45. 
Nicola, F., Mukh Mintadi., Siswoyo. 2015. Hubungan Antara Konduktivitas , TDS (Total Dissolved Solid) dan TSS (Total Suspended Solid) dengan Kadar $\mathrm{Fe}^{2+}$ dan $\mathrm{Fe}$ Total Pada Sumur Air Gali di Daerah Sumbersari, Puger dan Kencong Kabupaten Jember. Prosiding Seminar Nasional Kimia.

Pusparinda, L dan R.I.B. Santoso. 2016. Studi Literatur Perencanaan Floating Treatment Wetland di Indonesia. Jurnal Teknik ITS . Vol. 5 No. 2. Pages A471A475.

Sample, D.J. and L.J. Fox. 2013. Innovative Best Management Fact Sheet No.1: Floating Treatment Wetlands. Publication BSE-76P.

Sari, P., Sudarno, Wisnu, I. 2015. Pengaruh Jumlah Tanaman Cyperus Alternifolius dan Waktu Tinggal Limbah Dalam Penyisihan Kadar Ammoniak, Nitrit, Dan Nitrat (Studi Kasus : Pabrik Minyak Kayu Putih). Jurnal Teknik Lingkungan, Vol. 4 No. 2. Hal 1-9.
Setiyanto, R. A., Darundiati, Y. H., Joko, T. 2016. Efektivitas Sistem Constructed Wetlands Kombinasi Malati Air (Echinodorus Palaefolius) dan Karbon Aktif Dalam Menurunkan Kadar COD (Chemical Oxygen Demand) Limbah Cair Rumah Sakit Banyumanik Semarang. Jurnal Kesehatan Masyarakat (e-Journal). Vol. 4 No. 1. Hal 436-441.

Sunanisari S, A. B. Santoso, E. Mulyana, S. Nomosatryo, dan Y.Mardiyati. 2008. Penyebaran Populasi Tumbuhan Air di Danau Singkarak. Limnotek. Vol. 15 No. 2. Hal 112-119.

Sunjono, D.D dan S.S. Moersidik. 2015. Kajian Karaktersitik Muara Ciliwung dengan Model Budget Nitrogen. J. Manusia dan Lingkungan. Vol. 22 No. 1. Hal 32 - 38.

Winston, R.J., William F. Hunt, Shawn G. Kennedy, Laura S. Merriman, Jacob Chandler, David Brown. 2013. Evaluation of Floating Treatment Wetlands as Retrofits to Existing Stormwater Retention Ponds. Ecological Engineering. Vol. 54. Pages 254-265. 